\title{
The inflammatory function of human IgA
}

\author{
Ivo S. Hansen ${ }^{1,2} \cdot$ Dominique L. P. Baeten $^{1,2} \cdot$ Jeroen den Dunnen ${ }^{1,2} \mathbb{C}$
}

Received: 17 September 2018 / Revised: 23 October 2018 / Accepted: 22 November 2018 / Published online: 29 November 2018 (c) The Author(s) 2018

\begin{abstract}
The prevailing concept regarding the immunological function of immunoglobulin $\mathrm{A}(\operatorname{Ig} \mathrm{A})$ is that it binds to and neutralizes pathogens to prevent infection at mucosal sites of the body. However, recently, it has become clear that in humans $\operatorname{IgA}$ is also able to actively contribute to the initiation of inflammation, both at mucosal and non-mucosal sites. This additional function of IgA is initiated by the formation of immune complexes, which trigger $\mathrm{Fc}$ alpha Receptor I (Fc $\alpha \mathrm{RI}$ ) to synergize with various other receptors to amplify inflammatory responses. Recent findings have demonstrated that co-stimulation of Fc $\alpha$ RI strongly affects pro-inflammatory cytokine production by various myeloid cells, including different dendritic cell subsets, macrophages, monocytes, and Kupffer cells. Fc $\alpha$ RI-induced inflammation plays a crucial role in orchestrating human host defense against pathogens, as well as the generation of tissue-specific immunity. In addition, FcoRI-induced inflammation is suggested to be involved in the pathogenesis of various chronic inflammatory disorders, including inflammatory bowel disease, celiac disease, and rheumatoid arthritis. Combined, IgA-induced inflammation may be used to either promote inflammatory responses, e.g. in the context of cancer therapy, but may also provide new therapeutic targets to counteract chronic inflammation in the context of various chronic inflammatory disorders.
\end{abstract}

Keywords FcaRI $\cdot$ Myeloid cells $\cdot$ Cytokines $\cdot$ Inflammation $\cdot$ Autoimmunity

\section{Introduction}

Antibodies are an integral part of the human immune system. Of the five different classes of antibodies that are found in humans ( $\operatorname{Ig} \mathrm{A}, \operatorname{IgD}, \operatorname{IgE}, \operatorname{IgG}$, and $\operatorname{Ig} M), \operatorname{Ig} \mathrm{A}$ is by far the most produced antibody in the human body, even surpassing all other classes combined [1]. Most of the IgA is present at mucosal sites, where it is produced as a dimer by locally residing plasma cells. IgA is also the second most abundant isotype in serum, where it is normally present at concentrations of $1-3 \mathrm{mg} / \mathrm{mL}$. In circulation, $\operatorname{IgA}$ is generally found as a monomer, which is produced by plasma cells located in the bone marrow.

Jeroen den Dunnen

j.dendunnen@amc.nl

1 Amsterdam Rheumatology and immunology Center, Academic Medical Center (AMC), Amsterdam, The Netherlands

2 Department of Experimental Immunology, Amsterdam Infection \& Immunity Institute, Amsterdam UMC, University of Amsterdam, Meibergdreef 9, Amsterdam, The Netherlands
There are two IgA subtypes found in humans, IgA1 and $\operatorname{IgA} 2$. The subtypes differ at various sites in the heavy chain, however the most notable difference is found in the hinge region where $\operatorname{IgA} 2$ lacks 13 amino acids compared to IgA1 (see Fig. 1a for a schematic overview). Truncation of the hinge region in IgA2 leads to a reduced susceptibility to IgA1 bacterial proteases, which possibly explains the higher prevalence of $\operatorname{Ig} \mathrm{A} 2$ in mucosal secretions.

The main function of $\operatorname{IgA}$ has long been considered to be mostly 'passive' or anti-inflammatory. However, recently IgA has emerged as an inducer of 'active' immunity by controlling cytokine and chemokine production. In this review, we will briefly mention the passive function of $\operatorname{IgA}$, but will subsequently focus on the inflammatory function of $\operatorname{IgA}$ in humans in the context of health and disease.

\section{Passive immunity by IgA: immune exclusion, neutralization, and antigen excretion}

The most well-known function of IgA is that it provides passive immunity, through immune exclusion, pathogen neutralization, and antigen excretion, particularly 


\section{A}

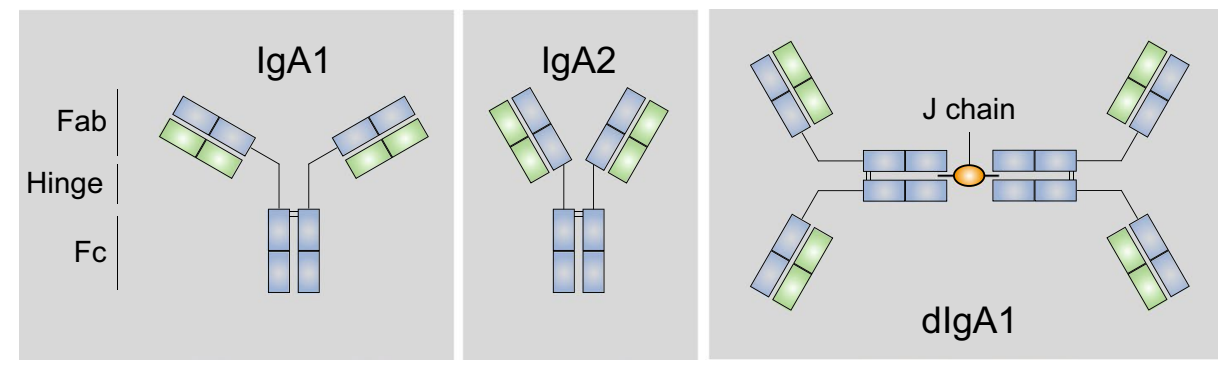

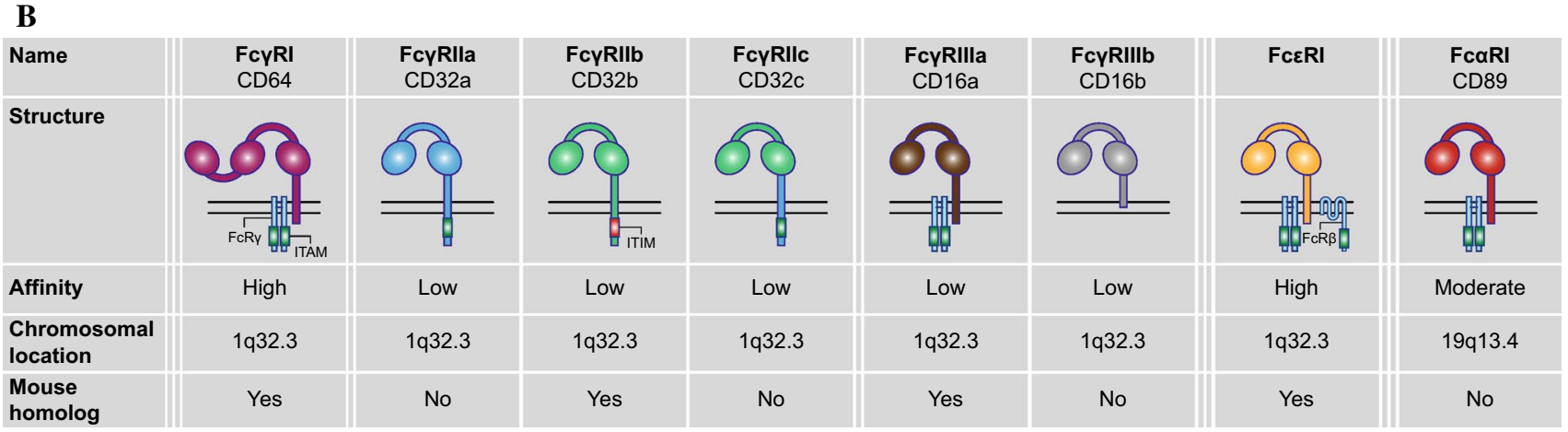

Fig. 1 The human Fc receptor family. a $\operatorname{IgA}$ molecules consist of two domains, which are linked by a hinge region. $\operatorname{IgA} 2$ molecules have a shorter hinge region than IgA1, leading to a more Y-shaped conformation. The antigen-binding domain $(\mathrm{Fab})$ binds to antigens, while the crystallizable fragment $(\mathrm{Fc})$ domain can be recognized by Fc receptors. Furthermore, one molecule is made up of two identical heavy chains (in blue) and two identical light chains (in green). $\operatorname{IgA}$ molecules can be expressed as dimers when the Fc domains are con- nected to each other by a joining (J) chain. b Human FcRs are divided according to their binding capability to antibody subtype, Fc $\gamma R$, FceR, and $F c \alpha R$. Fc $\gamma$ Rs can be further subdivided into three types: Fc $\gamma$ RI, Fc $\gamma$ RII, and Fc $\gamma$ RIII, which can be grouped based on their binding affinity to IgG (with Fc $\gamma$ RI being the only high-affinity receptor). Fc $\alpha \mathrm{RI}$ is genetically located on a distinct location apart from the other receptors. The human FcR family differs quite significantly from the mouse FcR family at mucosal sites such as the gastrointestinal tract. In the intestine, $\operatorname{Ig} \mathrm{A}$ is produced in large quantities in dimeric form by plasma cells in the lamina propria, which contain the joining $\mathrm{J}$ chain that allows transportation over the epithelium by the poly Ig receptor and excretion into the lumen as secretory $\operatorname{Ig} \mathrm{A}(\mathrm{S} \operatorname{Ig} \mathrm{A})[2,3]$. SIgA binds to both bacteria as well as bacterial products and is thereby able to prevent their interaction with the epithelium. Locally produced IgA by plasma cells in the lamina propria of the intestine is tailored to recognize the microbiota present in the lumen and particularly targets pathogenic bacteria [4]. During transport of $\operatorname{IgA}$ through the intestinal epithelial cells it is already able to bind to its target, which both facilitates excretion of antigens back into the lumen that have reached the lamina propria, but also neutralizes intracellular pathogens in the epithelial cells [5]. These functions of IgA have been called passive immunity and have long been thought to be the main role of IgA. Although this function of $\operatorname{IgA}$ is very important for homeostasis, several excellent reviews [5-7] cover this subject in detail and we will not further discuss it here.

\section{Active immunity by IgA: amplification or inhibition of cytokine production}

In addition to the well-known passive functions, it has more recently become clear that IgA can also actively control immune responses. This immune activating function of $\operatorname{IgA}$ is effectuated by modulating the production of various key cytokines such as TNF and IL- $1 \beta$ by human myeloid immune cells, which is a pivotal step in controlling local and systemic immunity. In this regard, IgA has a dual role, as it can induce both inflammatory and immunosuppressive responses. Crucial for the active immune function of $\operatorname{Ig} \mathrm{A}$ is the binding to its receptor. Although different $\operatorname{Ig} \mathrm{A}$ receptors have been described (see Box 1 for an overview), the main IgA receptor that has been identified to be responsible for IgA-induced cytokine responses appears to be Fc alpha receptor (Fc $\alpha \mathrm{RI}$; also known as CD89) [8]. Fc $\alpha \mathrm{RI}$ is one of the members of the family of Fc receptors, although it has some key distinctions which sets it apart from, e.g. the $\mathrm{Fc} \gamma$ receptors (recognizing IgG) 
or Fce receptor (recognizing IgE) (Fig. 1b). Fc $\alpha$ RI expression is restricted to the myeloid immune cell compartment and has been identified on neutrophils, monocytes, eosinophils, macrophages, and particular subsets of DCs such as intestinal $\mathrm{CD}_{103^{+}}$DCs and monocyte-derived DCs [8-13]. Fc $\alpha$ RI does not contain any signaling motives in its cytoplasmic tail, but instead Fc $\alpha$ RI relays signaling by association with the $\mathrm{Fc}$ receptor gamma chain $(\mathrm{FcR} \gamma)$, which contains an immunoreceptor tyrosine-based activation motifs (ITAM). Previously, Fc $\alpha$ RI activation has been shown to lead to a variety of immune processes including degranulation, phagocytosis, chemotaxis, and antibodydependent cellular cytotoxicity (ADCC) [14]. In contrast, FcoRI has long been considered to be a very poor inducer of cytokines by immune cells. Interestingly, Fc $\alpha$ RI has no direct homolog in mice $[15,16]$, and since most of our knowledge on FcRs comes from mouse studies, this may partly explain why Fc $\alpha$ RI-induced control of cytokine production has so long been underexposed.

Control of cytokine expression by antigen-presenting cells (APC) is essential for controlling inflammation and inducing both innate and adaptive responses [17, 18]. Generally, cytokine production is induced by APCs upon recognition of components of pathogens by several families of receptors, collectively known as pattern recognition receptors (PRR). These include the Toll-like receptors (TLR) [19], NOD-like receptors (NLR) [20], C-type lectin receptors (CLR) [21], and RIG-I-like receptors [22]. However, the immune response by APCs is not determined by stimulation of a single receptor, but rather a cooperation of multiple receptors [23-26].

A key feature of IgA-induced cytokine production is that FcoRI stimulation does not elicit cytokine production when stimulated individually, but that Fc $\alpha$ RI collaborates with other receptors (mostly PRRs) to amplify or inhibit the production of specific cytokines. Notably, the ultimate FcoRI-induced cytokine profile is not uniform, but instead appears to be tailored to the immunological context, which depends on (1) the receptor that FcoRI interacts with, (2) the cell type involved, and (3) whether IgA binds to FcoRI in soluble or aggregated form. Below, we will discuss the role of $\mathrm{Fc} \alpha \mathrm{RI}$ and $\operatorname{IgA}$ in regulating cytokine production in various tissues as well as its relevance to understanding and potential treatment of human diseases.

\section{Inhibitory signaling by $\lg A$}

The immunosuppressive function of monomeric or dimeric IgA has been known for decades [27]. Yet, the molecular mechanism behind this has long been unclear. In recent years, it has been described that Fc $\alpha$ RI-induced ITAM signaling (which originally was only considered to promote inflammatory responses) can also negatively control inflammatory responses $[28,29]$. This anti-inflammatory function of ITAMs has been named inhibitory ITAM (ITAMi), and has also been described for other receptors such as Fc $\gamma$ RIIa and FcyRIII [30, 31]. Due to the low affinity of IgA monomers and dimers for Fc $\alpha$ RI, circulating and unbound IgA bind only transiently, which results in ITAMi signaling under homeostatic conditions. This steady-state inhibitory signaling results in inhibition of several inflammatory processes, such as oxidative burst activity, chemotaxis and $\mathrm{IgG} \mathrm{Fc}$ receptor mediated phagocytosis, as well as cytokine production [32-35]. For example, Pasquier et al. identified that stimulation of FcoRI with soluble $\operatorname{IgA}$ inhibits FceRI-induced degranulation of mast cells, which prevents IgE-mediated asthma in transgenic mice expressing human Fc $\alpha$ RI on myeloid cells [28]. In addition, Olas et al. showed that serum IgA suppresses the production of pro-inflammatory cytokines such as TNF and IL-6 from LPS-stimulated monocytes and PBMCs [36]. Mechanistically, the binding of monomeric or dimeric IgA is unable to cross-link Fc $\alpha R I$, causing transient Syk recruitment followed by recruitment of Src homology region 2 domain-containing phosphatase-1 (SHP-1) to the Fc receptor gamma chain (FcR $\gamma$ ). Fc $\alpha$ RI and SHP-1 are then recruited to lipid rafts where both activating and inhibitory receptors are present, in a cluster known as an inhibisome. Due to the heterologous nature of these inhibisomes, activating signals are inhibited by the recruited SHP-1 resulting in inhibitory signaling [28, 37]. In summary, inhibition through FcaRI by monomeric or dimeric IgA plays an active role in homeostasis by suppression of inflammatory functions via ITAMi signaling.

\section{IgA-induced inflammation in host defense}

Although Fc $\alpha$ RI suppresses pro-inflammatory cytokine production under homeostatic conditions by ITAMi signaling, it also plays a crucial role in promoting inflammation during infection. The key to this switch from immune suppression to inflammation by FcoRI lies in the formation of IgA immune complexes. While under homeostatic conditions mainly monomeric and soluble $\operatorname{IgA}$ is present, IgA immune complex formation occurs when IgA aggregates are formed, e.g. when invading bacteria become opsonized with $\operatorname{IgA}$, during secondary infection or by cross-reactivity of antibodies to pathogen structures [38-40]. Fc $\alpha$ RI binds monomeric and dimeric $\operatorname{IgA}$ with moderate affinity $\left(\mathrm{Ka}=\sim 10^{6} / \mathrm{M}\right)$, while IgA immune complexes bind avidly to FcoRI [14, 41], which upon binding induces classic ITAM signaling. Although IgA immune complexes can directly activate effector functions such as phagocytosis and degranulation [8], individual Fc $\alpha$ RI stimulation does not directly induce cytokine production. Instead, FcoRI strongly amplifies 


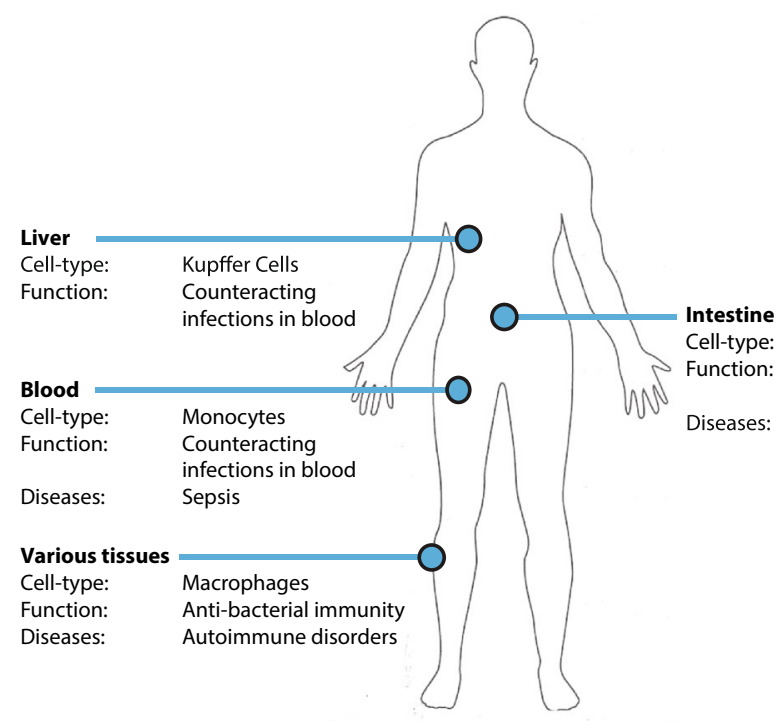

CD103+ Dendritic Cells

Counteracting

infections in lamina propria

Inflammatory Bowel Disease
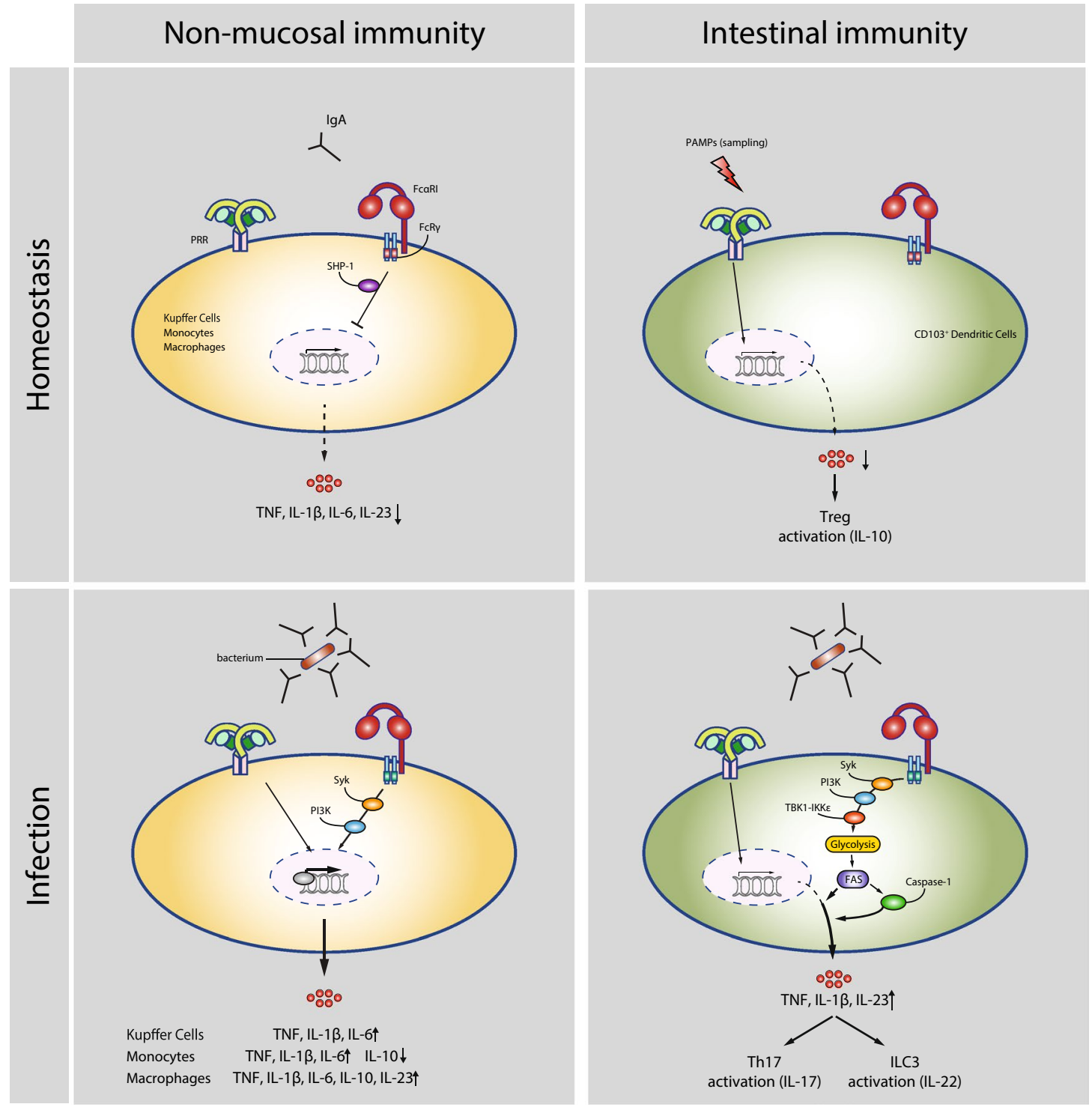

\section{Intestinal immunity}
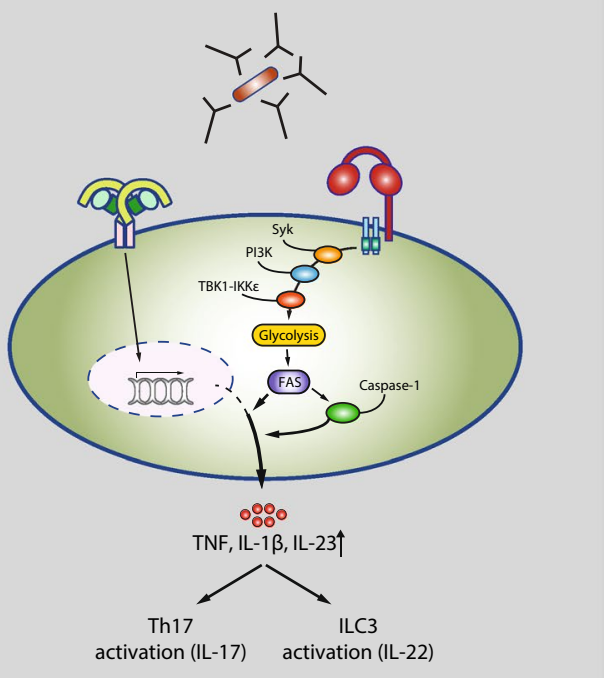
४Fig. 2 Tissue-specific Fc $\alpha$ RI-mediated control of cytokine production in homeostasis and infection. FcoRI mediates both inflammatory and immunosuppressive responses in a cell-type and tissue-specific manner. Fc $\alpha$ RI directs cytokine production under different conditions. Homeostasis: in non-mucosal tissues, monomeric $\operatorname{IgA}$ recognition by Fc $\alpha$ RI during homeostasis leads to inhibition of pro-inflammatory cytokine production through ITAMi-mediated SHP-1 recruitment. In intestinal immunity, $\mathrm{CD} 103^{+} \mathrm{DCs}$ tolerogenic conditioning leads to activation through PRRs, which results into induction of regulatory $\mathrm{T}$ cells and IL-10 production. Infection: bacterial infection IgA immune complex formation is recognized by Fc $\alpha$ RI leading to crosstalk with PRRs and pro-inflammatory cytokine production in Kupffer cells, monocytes, and macrophages through Syk and PI3K-mediated up-regulation of transcription resulting in distinct expression of cytokines. Upon intestinal infection, $\operatorname{IgA}$ opsonization provides a second signal through FcoRI activating Syk, PI3K, and TBK1-IKKe, which increases the glycolytic flux and fatty acid synthesis (FAS) that results in an inflammatory response mediated by increased mRNA translation and caspase- 1 activation

inflammatory responses through collaboration with PRRs. As such, IgA immune complex formation functions as a danger signal that promotes inflammation in different tissues, which we will discuss below.

\section{IgA-induced inflammation in the intestine}

In the intestine, $\operatorname{Ig} \mathrm{A}$ is produced in vast quantities, where it provides both passive and active immunity. Yet, it is important to realize that in the intestine the active and passive immune functions of IgA appear to be spatiotemporally separated. In the lumen, SIgA continually provides passive immunity through immune exclusion of commensal bacteria. In contrast, in the lamina propria immune complexes of conventional IgA generate active immunity only upon infection by eliciting pro-inflammatory cytokine production by immune cells, which is a crucial feature for induction of protective immunity in the intestine.

In most tissues, the recognition of pathogens by innate immune cells through PRRs directly leads to inflammatory responses. However, considering the extremely high amount of commensal microorganisms and their products, PRR activation is a steady-state phenomenon in the lamina propria of the gastrointestinal tract, which does not induce inflammation, but instead drives immune tolerance [42]. Therefore, the intestinal immune system requires a second signal to discriminate between homeostatic conditions and infection. Recently, it has been identified that IgA immune complex formation in the lamina propria functions as one of those second signals. Upon infection, bacteria that penetrate the epithelial layer are opsonized by local (dimeric) IgA, which is tailored to an individual's microbiota and is mostly directed against colitogenic species [4, 39]. Remarkably, in the intestine only few Fc $\alpha$ RI-expressing cells are present under homeostatic conditions to detect these IgA immune complexes, since intestinal macrophages lack Fc $\alpha$ RI expression [13], and neutrophils and monocytes are mainly recruited after infection [43-45]. Instead, one of the main Fc $\alpha$ RI expressing cells for the initial recognition of IgA immune complexes in the intestine are a subset of DCs, characterized by the expression of CD103 ( $\alpha E \beta 7$ integrin) [46]. While under steady-state conditions PRR stimulation of these $\mathrm{CD}_{103^{+}}$DCs by bacteria promote immune tolerance through activation of regulatory $\mathrm{T}$ cells $[47,48]$, coactivation of Fc $\alpha$ RI by IgA-opsonized bacteria breaks the tolerance of human ex vivo and in vitro $\mathrm{CD} 103^{+} \mathrm{DCs}$ by strongly inducing key pro-inflammatory cytokines such as TNF, IL-1 $\beta$, and IL-23. This Fc $\alpha$ RI-PRR cross-talk on $\mathrm{CD}_{103^{+}} \mathrm{DCs}$ further promotes inflammation by activating $\mathrm{T}$ helper 17 (Th17) and intestinal type 3 innate lymphoid cells (ILC3) [46], which subsequently promotes neutrophil recruitment as well as tissue repair through IL-22 production $[49,50]$.

Combined, IgA-induced inflammation is critically involved in counteracting bacterial infections in the intestine by functioning as a second signal that converts otherwise tolerogenic DCs into pro-inflammatory cells, thereby, controlling the delicate balance between tolerance and inflammation (Fig. 2).

\section{IgA-induced inflammation in non-mucosal tissues by serum $\lg A$}

IgA is strongly associated with mucosal immunity. However, $\operatorname{IgA}$ is also the second most common antibody isotype in serum, where it is primarily expressed as a monomer [1]. Similar to the non-secreted form in the lamina propria of the intestine, serum IgA in both monomeric and dimeric form can also induce pro-inflammatory cytokine production through activation of various Fc $\alpha$ RI-expressing immune cells in different tissues, including liver, skin, and blood [51].

Invading pathogens that enter the bloodstream from the gastrointestinal tract will first be transported to the liver through the portal vein. Under homeostatic conditions, the resident macrophages in the liver, known as Kupffer cells, continually filter the blood from bacterial products originating from the intestine [52]. Under these basal conditions, Kupffer cells display immune tolerance to pathogen-derived molecules such as LPS [53, 54]. However, upon infection with intestinal bacteria, as frequently occurs in immunocompromised individuals [55-57], this tolerogenic response is converted to an inflammatory response. Kupffer cells highly express Fc $\alpha R I$, and it has long been known that IgA facilitates bacterial clearance in portal vein blood by Kupffer cells by promoting Fc $\alpha$ RI-induced phagocytosis [12]. However, in addition to phagocytosis, Fc $\alpha$ RI stimulation has recently 
also been shown to promote inflammation by Kupffer cells. Similar to the intestinal CD103 ${ }^{+} \mathrm{DCs}$, the formation of serum IgA immune complexes by opsonization of bacteria breaks the tolerance of Kupffer cells to portal vein bacterial structures, resulting in production of pro-inflammatory cytokine production such as TNF, IL-1 $\beta$, and IL-6 [51] (Fig. 2). These data indicate that in the liver IgA does not only mediate bacterial clearance, but that IgA also contributes to initiation of protective immunity by controlling the balance between immune tolerance and inflammation by Kupffer cells.

Fc $\alpha$ RI is also expressed by other cytokine-producing myeloid immune cells such as monocytes and macrophages, situated in blood and tissues, respectively. Similar to Kupffer cells, serum IgA immune complexes enhance both phagocytosis and pro-inflammatory cytokine production by these cells, of which the latter function is again achieved through cross-talk with PRRs. For example, Hansen et al. showed that Fc $\alpha$ RI stimulation with IgA immune complexes amplifies the PRR-induced production of pro-inflammatory cytokines such as TNF by human monocytes and macrophages [51]. However, importantly, the nature of the inflammatory response induced by IgA immune complex formation appears to be cell type-specific, since the ultimate cytokine profile induced by Fc $\alpha$ RI-PRR cross-talk differs depending on the cell type involved (summarized in Fig. 2). For example, while serum IgA immune complexes strongly suppress the production of the anti-inflammatory cytokine IL-10 by monocytes, IL-10 production is increased by macrophages [51]. Although the mechanism behind these cell type-specific cytokine profiles are still unknown, the physiological function of this IgA-mediated effect is most likely to provide tissue-specific immune responses to invading pathogens.

While the cytokine profile induced by Fc $\alpha$ RI-PRR crosstalk is cell-type specific, there is common ground in the amplification of Th17-promoting cytokines, such as IL-1 $\beta$, IL-6, IL-23, and TNF [58, 59]. This suggests that serum IgA-induced inflammation, either in the intestine, liver, blood, or skin, is particularly important for counteracting extracellular pathogens, such as bacteria and fungi [60].

\section{Distinct molecular mechanisms of IgA-induced inflammation}

Mechanistically, Fc $\alpha$ RI activation by complexed IgA has thus far been identified to amplify cytokine responses on three different levels, i.e. by increasing (1) gene transcription, (2) gene translation, and (3) caspase-1 activation for post-translational amplification. Remarkably, the underlying molecular mechanism of Fc $\alpha$ RI-induced cytokine production is cell-type specific. For example, FcoRI amplifies cytokine production in intestinal $\mathrm{CD} 103^{+} \mathrm{DCs}$ by strongly increasing gene translation (with no detectable effect on gene transcription) [46], while in Kupffer cells, monocytes, and macrophages Fc $\alpha$ RI co-stimulation increases pro-inflammatory gene transcription [51]. Below we will discuss the mechanistic differences and similarities between the different cell-types (for a schematic overview see Fig. 2).

The mechanism behind Fc $\alpha$ RI-TLR cross-talk is currently best understood in intestinal $\mathrm{CD}_{103}{ }^{+} \mathrm{DCs}$, where it was identified to depend on both amplified gene translation and caspase- 1 activation. In the intestine, the continuous PRR activation by microbial structures under steady-state conditions induces pro-inflammatory cytokine gene transcription, but not gene translation, resulting in a net outcome of nonresponsiveness or immune tolerance to intestinal microbiota. Yet, upon infection, IgA immune complexes activate Fc $\alpha$ RI on $\mathrm{CD} 103^{+} \mathrm{DCs}$, leading to activation of the kinases spleen tyrosine kinase (Syk) and phosphoinositide 3-kinase (PI3K), which are classical components of $\mathrm{Fc}$ receptor gamma chain (FcR $\gamma$ ) signaling [61, 62]. Subsequently, downstream Fc $\alpha$ RI signaling through kinases TBK1 and IKKع ultimately results in amplification of both gene translation (of TLR-induced mRNA) and caspase- 1 activation (for post-translational amplification).

Importantly, both FcoRI-induced gene translation and caspase- 1 activation crucially depend on the induction of metabolic changes in $\mathrm{CD} 103^{+}$DCs. In recent years, it has become clear that for induction of pro-inflammatory responses these intracellular metabolic changes in immune cells are of crucial importance, which is collectively referred to as metabolic reprogramming [63]. Metabolic reprogramming is necessary to meet the high demands associated with inflammation, and is an essential process that occurs in various immune cells, including DCs, macrophages and T cells $[64,65]$. While previously particularly PRRs were considered to induce metabolic reprogramming, it has recently been identified that also $\operatorname{IgA}$, through Fc $\alpha \mathrm{RI}$, is able to induce metabolic changes in DCs [46]. Fc $\alpha$ RI activation strongly increases the glycolytic rate in $\mathrm{CD}_{103^{+}} \mathrm{DCs}$, which drives de novo synthesis of fatty acids for the expansion of the endoplasmic reticulum, which then enables gene translation of pro-inflammatory cytokines such as TNF [46] (Fig. 2).

In contrast to most of the pro-inflammatory cytokines, Fc $\alpha$ RI co-stimulation on $\mathrm{CD} 103^{+}$DCs does not enhance the gene translation of the pro-inflammatory cytokine IL-1 $\beta$. Instead, IgA immune complexes amplify IL- $1 \beta$ production through caspase- 1 activation, which is also dependent on Fc $\alpha$ RI-induced metabolic reprogramming. IL-1 $\beta$ is generally produced after PRR stimulation as an inactive pre-cursor, known as pro-IL-1 $\beta$, which has to be cleaved by caspase- 1 into its bioactive form [66]. FcoRI activates caspase-1 most likely through Syk-induced glycolysis and fatty acid 
synthesis, similar to the pathway that is activated by caspase- 1 activation by NLR family pyrin domain containing 3 (NLRP3) [67-69]. Thus, in CD $103^{+}$DCs, Fc $\alpha$ RI-induced amplification of cytokine production at both the translational and post-translational level crucially depend on metabolic reprogramming.

Compared to intestinal CD103 ${ }^{+} \mathrm{DCs}$, less is known about the molecular mechanisms of IgA-induced inflammation in liver, blood, and skin. Upstream signaling of FcoRI in Kupffer cells, monocytes, and macrophages is largely similar to $\mathrm{CD} 103^{+}$DCs in its dependence on Syk and PI3K [51]. However, the downstream mechanisms are clearly distinct, since in Kupffer cells, monocytes, and macrophages Fc $\alpha$ RI co-stimulation amplifies cytokine gene transcription, instead of translation. The reason for distinct Fc $\alpha$ RI signaling in intestinal $\mathrm{CD}_{103}{ }^{+} \mathrm{DCs}$ is still speculative, but could be related to the unique immunological milieu in the intestine $[70,71]$. Although Fc $\alpha$ RI-dependent caspase- 1 activation has not been studied in Kupffer cells, monocytes, and macrophages, this does seem likely to occur considering the discrepancy between IL- $1 \beta$ gene transcription and protein production [51]. Similarly, it is yet unknown whether Fc $\alpha$ RI stimulation also induces metabolic reprogramming in these cells. While metabolic reprogramming is not commonly involved in affecting gene transcription [72], it could be responsible for caspase-1 activation in these cells, similar to the $\mathrm{CD} 103^{+} \mathrm{DCs}$.

\section{IgA deficiency: compensation through IgG?}

Considering the crucial function of IgA-induced passive and active immunity, it is remarkable that $\operatorname{IgA}$ deficiency has relatively mild effects and is in fact one of the most common primary immunodeficiency [73]. The absence of symptoms in $\operatorname{IgA}$ deficiency points towards a high level of redundancy. Regarding the passive immune function of SIgA, IgM is considered to compensate for the lack of IgA, since $\operatorname{IgM}$ can be transported to mucosal surfaces using the same polymeric IgR as IgA [74, 75]. In contrast, it is less clear how the human immune system can compensate for the capacity of $\operatorname{IgA}$ to induce cytokine production, since this is unlikely to also depend on IgM. Here, we propose that IgG may be important to compensate for this active immune function of $\operatorname{Ig} \mathrm{A}$. $\operatorname{IgG}$ is present in the lamina propria of the intestine [76] and is expressed in serum in even higher concentrations than IgA [77]. Furthermore, most cytokine-producing FcoRI-expressing myeloid cells also express Fc $\gamma$ Rs, including intestinal $\mathrm{CD} 103^{+}$DCs, monocytes, and macrophages [78, 79]. In addition, cytokine production and subsequent immune cell activation is remarkably similar between Fc $\alpha$ RI and Fc $\gamma R s$, since they both promote Th17 responses upon recognition of opsonized bacteria $[80,81]$. In this regard, it is also interesting that IgA-deficient patients with concurrent deficiency of $\operatorname{IgG} 2$, the main $\operatorname{IgG}$ subclass directed against bacteria [82], are more symptomatic, which includes upper respiratory tract infections and diarrhea [83, 84]. Since Fc $\gamma$ R-induced cytokine production has indeed been demonstrated for intestinal CD103 ${ }^{+}$DCs [46], monocytes [85, 86], and several macrophage subsets [87-89], it, therefore, seems likely that $\operatorname{IgG}$ can compensate for the loss of $\operatorname{IgA}$ in various tissues, including the lamina propria of the intestine, blood, and skin.

Remarkably, IgA deficiency is associated with several chronic inflammatory disorders, including rheumatoid arthritis, systemic lupus erythematosus, and celiac disease [75]. The reason for the association between IgA deficiency and these disorders is still largely unclear. One possibility is that low concentrations of soluble IgA result in less ITAMidependent immune suppression under homeostatic conditions, thereby lowering the threshold for immune activation. In contrast to this lack of soluble IgA, the presence of IgA immune complexes can also contribute to the development of these chronic inflammatory disorders, as discussed in the next paragraph.

\section{IgA-induced inflammation in inflammatory diseases}

Although the physiological function of IgA-induced inflammation is to provide host defense by counteracting bacterial infections, undesired or excessive activation of this mechanism may lead to pathology by contributing to the development of chronic inflammation. IgA-induced inflammation could worsen pathology in IBD patients, since the damaged epithelium leads to massive presence of IgA immune complexes (from opsonized commensal bacteria) in the lamina propria. In addition, several autoimmune disorders, such as RA, SLE and celiac disease, are characterized by the presence of IgA autoantibodies. These autoantibodies can form immune complexes, thereby undesirably instigating local and/or systemic inflammation. Next, we will discuss FcoRImediated inflammation in the context of various chronic inflammatory disorders.

\section{Inflammatory bowel disease}

IBD is a chronic relapsing disorder of the intestinal tract which is characterized by gastrointestinal inflammation and disruption of the epithelium. IBD encompasses all inflammatory bowel disorders, of which there are two major forms, Crohn's disease and ulcerative colitis [90]. These disorders differ in both clinical as well as pathological features, suggesting distinct pathogeneses. However, already decades ago 
it has been described that altered cytokine expression by immune cells in the intestinal lamina propria is associated with inflammation in both IBD forms [91, 92].

IBD patients are characterized by impaired barrier function of the intestinal epithelial layer, resulting in influx of IgA-opsonized bacteria. As a result of the presence of these IgA immune complexes in the lamina propria, Fc $\alpha$ RIinduced inflammation is very likely to be chronically activated in IBD patients. Indeed, the cytokines that are amplified by Fc $\alpha$ RI cross-talk in the intestine are also strongly associated with the pathogenesis of IBD. TNF plays a central role in IBD pathogenesis, which is evident by the current use of TNF inhibition for as a standard therapy for both Crohn's disease and ulcerative colitis [93, 94]. In addition, both IL-1 $\beta$ and IL-23 are implicated in the pathogenesis of Crohn's disease, with anti-IL-23 antibodies as an important candidate for therapeutic use [95].

Although IgA-induced inflammation is very likely to occur in the intestine of IBD patients, it is less clear how it affects the pathogenesis of the disease. Theoretically, Fc $\alpha$ RIinduced inflammation could play a role in IBD pathogenesis by either being overactive, or by being impaired. On the one hand, considering the powerful pro-inflammatory response induced by IgA-induced inflammation, a predisposition of individuals for prolonged and/or excessive activation of this mechanism could lead to extensive collateral damage, and as such contribute to IBD pathogenesis. But on the other hand, impaired IgA-induced inflammation could lead to chronic inflammation as well. The main physiological function of IgA-induced inflammation is to provide protective immunity against invading pathogens, and, therefore, impaired functionality could hamper the orchestration of intestinal anti-bacterial immune responses, which eventually could also lead to chronic bacterial infection and inflammation. In this regard, it is important to note that FcoRI stimulation of intestinal DCs does not only induce inflammation, but also stimulates tissue repair in the intestine, by strongly increasing the production of IL-22 by ILC3 [46].

Thus, while IgA-induced inflammation is active in inflamed tissue of IBD patients, it is still unclear whether it contributes to IBD pathogenesis by either being overactive (leading to excessive activation), or by being impaired (leading to insufficient host defense against bacteria, ultimately also resulting in chronic infection and inflammation).

\section{Celiac disease}

Celiac disease is an inflammatory disorder of the small intestine, which is characterized by presence of autoantibodies and $\mathrm{T}$ cell-mediated destruction. In celiac disease patients, exposure to the dietary antigen gluten is the causative pathological factor [96, 97]. Exposure to gluten leads to lesions in the small intestine characterized by villous blunting, epithelial crypt cell hyperplasia and leukocyte infiltration including plasmacytosis in the lamina propria [97].

In addition to antibodies against gluten, celiac disease patients express high levels of autoantibodies against the enzyme transglutaminase 2 [98], which is produced locally in the mucosa of the intestine [99]. On average $10 \%$ of plasma cells in a disease lesion are directed against transglutaminase 2 and, importantly, most of these plasma cells produce antibodies of the IgA isotype [100]. The abundant presence of the autoantigen, leading to the formation of $\operatorname{IgA}$ immune complexes, in combination with commensal bacteria that can enter via the lesions is, therefore, very likely to promote inflammation through FcoRI-PRR cross-talk. Hence, Fc $\alpha$ RI-induced inflammation by IgA autoantibodies are likely to worsen the pathology in patients suffering from celiac disease.

\section{Rheumatoid arthritis}

RA is a chronic autoimmune disease occurring in $1 \%$ of the population and is characterized by inflammation and damage of the joints. Although the pathogenesis is not fully understood, it is clear that pro-inflammatory cytokines such as TNF play a crucial role, which is underlined by the great clinical improvement after neutralization of these cytokines $[101,102]$. One of the hallmarks of RA is the presence of autoantibodies. The most prominent of these autoantibodies present in RA patients are anti-citrullinated protein antibodies (ACPA) and rheumatoid factor (RF), which are already present long before the onset of disease [103, 104]. ACPA recognize citrullinated extracellular matrix proteins in the joint, while RF binds to the Fc part of IgG antibodies. The binding of these autoantibodies to their antigens leads to the formation of large insoluble immune complexes [105], which in turn enable their recognition by Fc receptors.

The autoantibodies present in RA patients can be of various isotypes, including IgA [106]. The presence of IgA rheumatoid factor (RF) has been recognized as a predictive marker for RA, leading to increased systemic cytokine production [106, 107]. Furthermore, ACPA immune complexes formed in the presence of IgA RF lead to increased expression of RA-associated cytokines [108]. Myeloid immune cells such as monocytes and macrophages that recognize these immune complexes are also the main cellular source of pathogenic pro-inflammatory cytokines such as TNF, IL-1 $\beta$, and IL-6. However, similar to its function in host defense against bacteria, FcoRI essentially needs to collaborate with PRRs to induce cytokine production. In RA synovia, PRR activation is not induced by microbial compounds, but by endogenous ligands that are present as a result of tissue damage and cell death, 
and which are generally referred to as damage-associated molecular patterns (DAMPs) [109]. Combined, IgA immune complexes and PRR ligands particularly drive the production of RA-associated pro-inflammatory cytokines by myeloid immune cells $[51,81]$.

Taken together, FcoRI, particularly in synergy with PRRs, may contribute to RA pathogenesis by promoting pro-inflammatory cytokine production in response to $\operatorname{Ig} \mathrm{A}$ autoantibodies, similar to the more established pathogenic function of Fc $\gamma$ Rs [110-113].

\section{Other autoimmune diseases: IgA nephropathy, linear IgA bullous disease, and dermatitis herpetiformis}

In addition to aforementioned diseases, there are various other disorders that are characterized by the presence of autoantibodies of the $\operatorname{IgA}$ isotype. In principle, Fc $\alpha$ RI-PRR crosstalk will occur in any disorder in which the combination of IgA immune complexes, (endogenous or microbial) PRR ligands, and Fc $\alpha$ RI/PRR expressing immune cells are present. Although at this time there is still little direct evidence, several diseases are likely to fulfil these criteria. An important example is $\operatorname{IgA}$ nephropathy, the most prevalent form of primary glomerulonephritis that often leads to end-stage kidney failure. In IgA nephropathy patients, IgA immune complexes accumulate in the glomerular mesengium [114]. These IgA immune complexes promote macrophage infiltration and induce the release of pro-inflammatory cytokines in Fc $\alpha$ RI transgenic mice, which interestingly is not only dependent on FcoRI but also on transferrin receptor I $[115,116]$.

IgA immune complexes may also play a role in skin blistering diseases such as linear IgA bullous disease and dermatitis herpetiformis. Linear $\operatorname{IgA}$ bullous disease patients are characterized by expression of IgA autoantibodies against collagen XVII, a transmembrane protein involved in maintaining cell-matrix adhesion in the skin [117]. In addition to neutrophils that are recruited to the inflamed skin and are activated by $\mathrm{F} c \alpha \mathrm{RI}$ stimulation to induce tissue damage [118], IgA immune complexes may promote inflammation in a similar manner by eliciting Fc $\alpha$ RI-induced pro-inflammatory cytokines. Dermatitis herpetiformis is clinically similar to linear IgA bullous disease, and is also characterized by the presence of IgA autoantibodies in the skin. Dermatitis herpetiformis is strongly associated with celiac disease [119] and, therefore, could induce IgA-induced inflammation in skin in a similar manner as celiac disease drives intestinal inflammation. Future studies are needed to establish whether IgA-induced pro-inflammatory cytokine production is indeed involved in the pathogeneses of these diseases.

\section{Therapeutic opportunities}

As discussed above, the stimulation of FcoRI with IgA immune complexes, in cooperation with PRRs, promotes inflammatory cytokine responses. During infection, IgA-induced inflammation allows for a tailored immune response to counteract invading pathogens. However, when overactive or deficient, it may also lead to the development of chronic inflammation. Therefore, modification of IgAinduced cytokine responses may provide opportunities for therapeutic intervention, either by reducing or enhancing these inflammatory responses.

Intravenous immunoglobulin (IVIG) treatment has been used for several decades now to treat inflammatory disorders. Initially it was used as therapy for immunocompromised patients as a replacement therapy but was shown to have antiinflammatory effects. IVIG is mostly based on the immunomodulatory function of IgG [120]. However, as discussed earlier, in its monomeric form IgA also has the ability to induce inhibitory signaling via FcoRI. In transgenic mice that express human FcoRI on monocytes/macrophages this leads to a reduction of arthritis via ITAMi signaling [121]. While IgA has been associated with immunosuppression, to date still very few studies have been performed with intravenous IgA. This is most likely a combination between the difficulty of purifying $\operatorname{IgA}$, as well as the fast turn-over rate that IgA has in the systemic circulation, although $\mathrm{Fc}$ engineered IgA2 molecules have shown an improved pharmacokinetics in vivo [122, 123].

As an alternative to inducing immune suppression, it may be promising to specifically interfere with the downstream signaling that is responsible for Fc $\alpha$ RI-TLR cross-talk. Signaling molecules such as Syk, PI3K and TBK1-IKK $\varepsilon$ have been identified as pivotal players in the induction of cytokines by FcoRI [46, 51]. Interestingly, disease activity in RA patients was significantly reduced by therapeutic inhibition of Syk using oral small-molecule inhibitor R788 [124]. In addition, Syk expression in intestinal DCs was shown to play an important role in inducing colitis in mice [125] indicating that inhibition of Syk could be helpful for IBD patients. Therapeutic inhibitors for PI3K are being developed as well, most for treatment in cancer, but some are also being tested for application in inflammatory disorders [126, 127]. It is yet unclear which form of PI3K is required for Fc $\alpha$ RI-PRR cross-talk, and, therefore, narrowing this down could help with precisely targeting IgA-induced inflammation in chronic inflammatory disorders. Therapeutic TBK1-IKK $\varepsilon$ inhibitors Amlexanox and Rebamipide are already in clinical use for inflammatory disorders such as asthma and gastric ulcers $[128,129]$ and may be used to target IgA-induced inflammation. Additionally, Fc $\alpha$ RI-TLR cross-talk was identified to depend fatty acid synthase (FAS) activity, for which inhibitors are now being developed and tested in the context of cancer treatment $[130,131]$. When effective, inhibition of FAS 
could have therapeutic potential in inflammatory disorders as well. Further elucidation of the involved signaling pathways in Fc $\alpha$ RI-TLR cross-talk may extend the repertoire of smallmolecule inhibitors that can be used for the treatment of chronic inflammatory disorders.

While interfering with Fc $\alpha$ RI-induced cytokine production may be beneficial in the treatment of autoimmune disorders, enhancing inflammation could provide new opportunities in the treatment of diseases such as cancer [132]. The local environment of solid tumors is dominated by the presence of myeloid derived suppressor cells, including the presence of antiinflammatory M2 macrophages, which inhibit the generation of effective anti-tumor responses [133-135]. Since M2 macrophages express FcoRI, (co-)stimulation of these cells may convert these anti-inflammatory cells into pro-inflammatory cells, similar to the conversion of other tolerogenic immune cells such as Kupffer cells and intestinal DCs [46, 51]. In this regard, it is interesting that human M2 macrophages have previously been shown to be converted to pro-inflammatory cells upon stimulation with $\operatorname{IgG}$ immune complexes that activate Fc $\gamma$ Rs [89]. This is especially interesting since IgA has been shown to have a greater therapeutic potential in treating solid tumors than IgG, since IgA is far more effective in mediating recruitment of and killing by neutrophils [122, 123, 136-138]. Hence, the combination of $\operatorname{IgA}$ antibodies and an adjuvant such as a PRR agonist or IFN $\gamma$ to promote local inflammation, as well as the direct killing of tumor cells, may be a useful tool in the treatment of solid tumors.

Taken together, understanding the underlying mechanisms and cell-type specific responses of IgA-induced cytokine production could provide new therapeutic opportunities for a large variety of disorders, including chronic inflammatory disorders, autoimmune diseases, and cancer.

\section{Concluding remarks}

Here, we have discussed a novel property of $\operatorname{IgA}$ in inducing inflammation via $\mathrm{Fc} \alpha \mathrm{RI}$ in various tissues by directing cytokine responses. Yet, it is important to realize that Fc $\alpha$ RI also mediates various other immunological processes, including phagocytosis, degranulation, and ADCC. Notably, many of these processes will occur simultaneously, although sometimes by different cell types. Therefore, in view of therapeutic opportunities, it would be useful to specifically induce or interfere with one feature of FcoRI, while leaving other functions unharmed. In this regard, the recent findings that indicate that Fc $\alpha \mathrm{RI}$ signaling uses cell type-specific signaling pathways may provide opportunities to modulate IgA-induced cytokine responses in a tissue-specific, and perhaps even disease-specific, manner. However, to really exploit the targeting of distinct Fc $\alpha$ RI functions, more knowledge about the underlying molecular mechanisms of the different FcoRI functions in different human immune cells is required.

Acknowledgements This work was supported by Grants from the Dutch Digestive Foundation (MLDS; Career Development Grant), Amsterdam UMC (AMC fellowship 2015), The Netherlands Scientific Organization (NWO; VICI Grant), and the European Research Council (ERC; Consolidator Grant). MLDS and AMC Grants were awarded to J.d.D. NWO and ERC Grants were awarded to D.L.P.B.

\section{Compliance with ethical standards}

Conflict of interest D.L.P.B. is an employee of UCB.

Open Access This article is distributed under the terms of the Creative Commons Attribution 4.0 International License (http://creativeco mmons.org/licenses/by/4.0/), which permits unrestricted use, distribution, and reproduction in any medium, provided you give appropriate credit to the original author(s) and the source, provide a link to the Creative Commons license, and indicate if changes were made.

\section{Box 1: Other IgA receptors}

Several different receptors have been described to bind IgA. There are major differences in both affinity and function, which is summarized below.

- Poly Ig receptor is expressed on epithelial cells and is crucial for the transport of immunoglobulin to the lumen of mucosal tissues. The ligand for the PIgR is the J-chain and, therefore, it is able to bind both $\operatorname{IgA}$ and IgM. After binding, the receptor is internalized and transported across the cell, whereupon the immunoglobulin is released into the lumen $[2,3]$.

- Fc alpha/mu receptor is a receptor expressed on hematopoietic and non-hematopoietic cells, including B cells [139]. It binds both $\operatorname{IgM}$ and $\operatorname{Ig} A$ but has a much higher affinity for IgM [140]. IgA binding likely occurs during complex formation and has been associated with removal of IgA complexes from circulation.

- Transferrin receptor expressed on mesangial cells, epithelial cells, and B cells, where it is able to bind IgA1, but not IgA2 [141]. Transferrin receptor has been implicated in the formation of $\operatorname{IgA} 1$ complexes in IgA nephropathy $[142,143]$.

- Asialoglycoprotein receptor is a C-type lectin receptor, expressed on hepatic cells. It recognizes and binds to terminal galactose or $\mathrm{N}$-acetylgalactosamine residues. ASPGR has been shown to be involved in clearance of IgA from the circulation [144-146].

Other receptors, including FcRL4 [147], DC-SIGN/ SIGNR1 [148], SC-receptor [149], and M-cell receptor [150] have been described to bind IgA, but the exact role the binding plays is not well defined yet. 


\section{References}

1. Woof JM, Kerr MA (2006) The function of immunoglobulin A in immunity. J Pathol 208:270-282

2. Johansen FE, Braathen R, Brandtzaeg P (2001) The J chain is essential for polymeric Ig receptor-mediated epithelial transport of IgA. J Immunol 167:5185-5192

3. Lewis MJ, Pleass RJ, Batten MR, Atkin JD, Woof JM (2005) Structural requirements for the interaction of human $\operatorname{IgA}$ with the human polymeric Ig receptor. J Immunol 175:6694-6701

4. Palm NW, de Zoete MR, Cullen TW, Barry NA, Stefanowski J, Hao L, Degnan PH, Hu J, Peter I, Zhang W, Ruggiero E, Cho JH, Goodman AL, Flavell RA (2014) Immunoglobulin A coating identifies colitogenic bacteria in inflammatory bowel disease. Cell 158:1000-1010

5. Strugnell RA, Wijburg OL (2010) The role of secretory antibodies in infection immunity. Nat Rev Microbiol 8:656-667

6. Corthesy B (2013) Role of secretory IgA in infection and maintenance of homeostasis. Autoimmun Rev 12:661-665

7. Boyaka PN (2017) Inducing mucosal IgA: a challenge for vaccine adjuvants and delivery systems. J Immunol 199:9-16

8. Monteiro RC, Van De Winkel JG (2003) IgA Fc receptors. Annu Rev Immunol 21:177-204

9. Monteiro RC, Kubagawa H, Cooper MD (1990) Cellular distribution, regulation, and biochemical nature of an $\mathrm{Fc}$ alpha receptor in humans. J Exp Med 171:597-613

10. Monteiro RC, Hostoffer RW, Cooper MD, Bonner JR, Gartland GL, Kubagawa H (1993) Definition of immunoglobulin A receptors on eosinophils and their enhanced expression in allergic individuals. J Clin Invest 92:1681-1685

11. Geissmann F, Launay P, Pasquier B, Lepelletier Y, Leborgne M, Lehuen A, Brousse N, Monteiro RC (2001) A subset of human dendritic cells expresses IgA Fc receptor (CD89), which mediates internalization and activation upon crosslinking by IgA complexes. J Immunol 166:346-352

12. van Egmond $M$, van Garderen $E$, van Spriel AB, Damen CA, van Amersfoort ES, van Zandbergen G, van Hattum J, Kuiper J, van de Winkel JG (2000) FcalphaRI-positive liver Kupffer cells: reappraisal of the function of immunoglobulin A in immunity. Nat Med 6:680-685

13. Smith PD, Smythies LE, Mosteller-Barnum M, Sibley DA, Russell MW, Merger M, Sellers MT, Orenstein JM, Shimada T, Graham MF, Kubagawa H (2001) Intestinal macrophages lack CD14 and CD89 and consequently are down-regulated for LPS- and IgA-mediated activities. J Immunol 167:2651-2656

14. Bakema JE, van Egmond M (2011) The human immunoglobulin A Fc receptor FcalphaRI: a multifaceted regulator of mucosal immunity. Mucosal Immunol 4:612-624

15. Lux A, Nimmerjahn F (2013) Of mice and men: the need for humanized mouse models to study human IgG activity in vivo. J Clin Immunol 33(Suppl 1):S4-S8

16. Reljic R (2006) In search of the elusive mouse macrophage Fc-alpha receptor. Immunol Lett 107:80-81

17. Iwasaki A, Medzhitov R (2010) Regulation of adaptive immunity by the innate immune system. Science 327:291-295

18. Walsh KP, Mills KH (2013) Dendritic cells and other innate determinants of T helper cell polarisation. Trends Immunol 34:521-530

19. Kawai T, Akira S (2010) The role of pattern-recognition receptors in innate immunity: update on Toll-like receptors. Nat Immunol 11:373-384

20. Elinav E, Strowig T, Henao-Mejia J, Flavell RA (2011) Regulation of the antimicrobial response by NLR proteins. Immunity 34:665-679

21. Geijtenbeek TB, Gringhuis SI (2016) C-type lectin receptors in the control of $\mathrm{T}$ helper cell differentiation. Nat Rev Immunol $16: 433-448$
22. Loo YM, Gale M Jr (2011) Immune signaling by RIG-I-like receptors. Immunity 34:680-692

23. Trinchieri G, Sher A (2007) Cooperation of Toll-like receptor signals in innate immune defence. Nat Rev Immunol 7:179-190

24. Underhill DM (2007) Collaboration between the innate immune receptors dectin-1, TLRs, and Nods. Immunol Rev 219:75-87

25. Kawai T, Akira S (2011) Toll-like receptors and their crosstalk with other innate receptors in infection and immunity. Immunity 34:637-650

26. Nish S, Medzhitov R (2011) Host defense pathways: role of redundancy and compensation in infectious disease phenotypes. Immunity 34:629-636

27. Kerr MA (1990) The structure and function of human IgA. Biochem J 271:285-296

28. Pasquier B, Launay P, Kanamaru Y, Moura IC, Pfirsch S, Ruffie C, Henin D, Benhamou M, Pretolani M, Blank U, Monteiro RC (2005) Identification of FcalphaRI as an inhibitory receptor that controls inflammation: dual role of FcRgamma ITAM. Immunity $22: 31-42$

29. Blank U, Launay P, Benhamou M, Monteiro RC (2009) Inhibitory ITAMs as novel regulators of immunity. Immunol Rev 232:59-71

30. Aloulou M, Ben Mkaddem S, Biarnes-Pelicot M, Boussetta T, Souchet H, Rossato E, Benhamou M, Crestani B, Zhu Z, Blank U, Launay P, Monteiro RC (2012) IgG1 and IVIg induce inhibitory ITAM signaling through FcgammaRIII controlling inflammatory responses. Blood 119:3084-3096

31. Ben Mkaddem S, Hayem G, Jonsson F, Rossato E, Boedec E, Boussetta T, El Benna J, Launay P, Goujon JM, Benhamou M, Bruhns P, Monteiro RC (2014) Shifting FcgammaRIIA-ITAM from activation to inhibitory configuration ameliorates arthritis. J Clin Invest 124:3945-3959

32. Van Epps DE, Williams RC Jr (1976) Suppression of leukocyte chemotaxis by human IgA myeloma components. J Exp Med 144:1227-1242

33. Wilton JM (1978) Suppression by IgA of IgG-mediated phagocytosis by human polymorphonuclear leucocytes. Clin Exp Immunol 34:423-428

34. Van Epps DE, Reed K, Williams RC Jr (1978) Suppression of human PMN bactericidal activity by human IgA paraproteins. Cell Immunol 36:363-376

35. Wolf HM, Fischer MB, Puhringer H, Samstag A, Vogel E, Eibl MM (1994) Human serum IgA downregulates the release of inflammatory cytokines (tumor necrosis factor-alpha, interleukin-6) in human monocytes. Blood 83:1278-1288

36. Olas K, Butterweck H, Teschner W, Schwarz HP, Reipert B (2005) Immunomodulatory properties of human serum immunoglobulin A: anti-inflammatory and pro-inflammatory activities in human monocytes and peripheral blood mononuclear cells. Clin Exp Immunol 140:478-490

37. Pfirsch-Maisonnas S, Aloulou M, Xu T, Claver J, Kanamaru Y, Tiwari M, Launay P, Monteiro RC, Blank U (2011) Inhibitory ITAM signaling traps activating receptors with the phosphatase SHP-1 to form polarized "inhibisome" clusters. Sci Signal 4:ra24

38. Keasey SL, Schmid KE, Lee MS, Meegan J, Tomas P, Minto M, Tikhonov AP, Schweitzer B, Ulrich RG (2009) Extensive antibody cross-reactivity among infectious gram-negative bacteria revealed by proteome microarray analysis. Mol Cell Proteomics 8:924-935

39. Bunker JJ, Erickson SA, Flynn TM, Henry C, Koval JC, Meisel M, Jabri B, Antonopoulos DA, Wilson PC, Bendelac A (2017) Natural polyreactive IgA antibodies coat the intestinal microbiota. Science 358:eaan6619

40. Rollenske T, Szijarto V, Lukasiewicz J, Guachalla LM, Stojkovic K, Hartl K, Stulik L, Kocher S, Lasitschka F, Al-Saeedi M, Schroder-Braunstein J, von Frankenberg M, Gaebelein G, 
Hoffmann P, Klein S, Heeg K, Nagy E, Nagy G, Wardemann $\mathrm{H}$ (2018) Cross-specificity of protective human antibodies against Klebsiella pneumoniae LPS O-antigen. Nat Immunol 19:617-624

41. Reterink TJ, van Zandbergen G, van Egmond M, Klar-Mohamad N, Morton CH, van de Winkel JG, Daha MR (1997) Sizedependent effect of IgA on the IgA Fc receptor (CD89). Eur J Immunol 27:2219-2224

42. Joeris T, Muller-Luda K, Agace WW, Mowat AM (2017) Diversity and functions of intestinal mononuclear phagocytes. Mucosal Immunol 10:845-864

43. Fournier BM, Parkos CA (2012) The role of neutrophils during intestinal inflammation. Mucosal Immunol 5:354-366

44. Wera O, Lancellotti P, Oury C (2016) The dual role of neutrophils in inflammatory bowel diseases. J Clin Med 5:118

45. Bain CC, Mowat AM (2014) The monocyte-macrophage axis in the intestine. Cell Immunol 291:41-48

46. Hansen IS, Krabbendam L, Bernink JH, Loayza-Puch F, Hoepel W, van Burgsteden JA, Kuijper EC, Buskens CJ, Bemelman WA, Zaat SAJ, Agami R, Vidarsson G, van den Brink GR, de Jong EC, Wildenberg ME, Baeten DLP, Everts B, den Dunnen J (2018) FcalphaRI co-stimulation converts human intestinal CD103(+) dendritic cells into pro-inflammatory cells through glycolytic reprogramming. Nat Commun 9:863

47. Coombes JL, Siddiqui KR, Arancibia-Carcamo CV, Hall J, Sun CM, Belkaid Y, Powrie F (2007) A functionally specialized population of mucosal CD103 + DCs induces Foxp3 + regulatory T cells via a TGF-beta and retinoic acid-dependent mechanism. J Exp Med 204:1757-1764

48. Sun CM, Hall JA, Blank RB, Bouladoux N, Oukka M, Mora JR, Belkaid Y (2007) Small intestine lamina propria dendritic cells promote de novo generation of Foxp3 T reg cells via retinoic acid. J Exp Med 204:1775-1785

49. Lindemans CA, Calafiore M, Mertelsmann AM, O'Connor MH, Dudakov JA, Jenq RR, Velardi E, Young LF, Smith OM, Lawrence G, Ivanov JA, Fu YY, Takashima S, Hua G, Martin ML, O’Rourke KP, Lo YH, Mokry M, Romera-Hernandez M, Cupedo T, Dow L, Nieuwenhuis EE, Shroyer NF, Liu C, Kolesnick R, van den Brink MRM, Hanash AM (2015) Interleukin-22 promotes intestinalstem-cell-mediated epithelial regeneration. Nature 528:560-564

50. Aparicio-Domingo P, Romera-Hernandez M, Karrich JJ, Cornelissen F, Papazian N, Lindenbergh-Kortleve DJ, Butler JA, Boon L, Coles MC, Samsom JN, Cupedo T (2015) Type 3 innate lymphoid cells maintain intestinal epithelial stem cells after tissue damage. J Exp Med 212:1783-1791

51. Hansen IS, Hoepel W, Zaat SAJ, Baeten DLP, den Dunnen J (2017) Serum IgA immune complexes promote proinflammatory cytokine production by human macrophages, monocytes, and Kupffer cells through FcalphaRI-TLR cross-talk. J Immunol 199:4124-4131

52. Jenne CN, Kubes $P$ (2013) Immune surveillance by the liver. Nat Immunol 14:996-1006

53. Knolle P, Schlaak J, Uhrig A, Kempf P, Meyer zum Buschenfelde KH, Gerken G (1995) Human Kupffer cells secrete IL-10 in response to lipopolysaccharide (LPS) challenge. J Hepatol 22:226-229

54. Knolle PA, Germann T, Treichel U, Uhrig A, Schmitt E, Hegenbarth S, Lohse AW, Gerken G (1999) Endotoxin down-regulates $\mathrm{T}$ cell activation by antigen-presenting liver sinusoidal endothelial cells. J Immunol 162:1401-1407

55. Pignata C, Budillon G, Monaco G, Nani E, Cuomo R, Parrilli G, Ciccimarra F (1990) Jejunal bacterial overgrowth and intestinal permeability in children with immunodeficiency syndromes. Gut 31:879-882

56. Riordan SM, McIver CJ, Wakefield D, Thomas MC, Duncombe VM, Bolin TD (1999) Serum immunoglobulin and soluble IL-2 receptor levels in small intestinal overgrowth with indigenous gut flora. Dig Dis Sci 44:939-944

57. Taur Y, Pamer EG (2013) The intestinal microbiota and susceptibility to infection in immunocompromised patients. Curr Opin Infect Dis 26:332-337

58. Acosta-Rodriguez EV, Napolitani G, Lanzavecchia A, Sallusto F (2007) Interleukins 1beta and 6 but not transforming growth factor-beta are essential for the differentiation of interleukin 17-producing human T helper cells. Nat Immunol 8:942-949

59. Evans HG, Gullick NJ, Kelly S, Pitzalis C, Lord GM, Kirkham BW, Taams LS (2009) In vivo activated monocytes from the site of inflammation in humans specifically promote $\mathrm{Th} 17$ responses. Proc Natl Acad Sci U S A 106:6232-6237

60. Ouyang W, Kolls JK, Zheng Y (2008) The biological functions of T helper 17 cell effector cytokines in inflammation. Immunity 28:454-467

61. Poole A, Gibbins JM, Turner M, van Vugt MJ, van de Winkel JG, Saito T, Tybulewicz VL, Watson SP (1997) The Fc receptor gamma-chain and the tyrosine kinase Syk are essential for activation of mouse platelets by collagen. EMBO J 16:2333-2341

62. Gibbins JM, Briddon S, Shutes A, van Vugt MJ, van de Winkel JG, Saito T, Watson SP (1998) The p85 subunit of phosphatidylinositol 3-kinase associates with the Fc receptor gamma-chain and linker for activitor of $\mathrm{T}$ cells (LAT) in platelets stimulated by collagen and convulxin. J Biol Chem 273:34437-34443

63. O'Neill LA, Kishton RJ, Rathmell J (2016) A guide to immunometabolism for immunologists. Nat Rev Immunol 16:553-565

64. Pearce EJ, Everts B (2015) Dendritic cell metabolism. Nat Rev Immunol 15:18-29

65. O’Neill LA, Pearce EJ (2016) Immunometabolism governs dendritic cell and macrophage function. J Exp Med 213:15-23

66. Franchi L, Eigenbrod T, Munoz-Planillo R, Nunez G (2009) The inflammasome: a caspase-1-activation platform that regulates immune responses and disease pathogenesis. Nat Immunol 10:241-247

67. Moon JS, Hisata S, Park MA, DeNicola GM, Ryter SW, Nakahira K, Choi AMK (2015) mTORC1-induced HK1-dependent glycolysis regulates NLRP3 inflammasome activation. Cell Rep 12:102-115

68. Moon JS, Lee S, Park MA, Siempos II, Haslip M, Lee PJ, Yun M, Kim CK, Howrylak J, Ryter SW, Nakahira K, Choi AM (2015) UCP2-induced fatty acid synthase promotes NLRP3 inflammasome activation during sepsis. J Clin Invest 125:665-680

69. Duffy EB, Periasamy S, Hunt D, Drake JR, Harton JA (2016) FcgammaR mediates TLR2- and Syk-dependent NLRP3 inflammasome activation by inactivated Francisella tularensis LVS immune complexes. J Leukoc Biol 100:1335-1347

70. Varol C, Zigmond E, Jung S (2010) Securing the immune tightrope: mononuclear phagocytes in the intestinal lamina propria. Nat Rev Immunol 10:415-426

71. Farache J, Zigmond E, Shakhar G, Jung S (2013) Contributions of dendritic cells and macrophages to intestinal homeostasis and immune defense. Immunol Cell Biol 91:232-239

72. Everts B, Amiel E, Huang SC, Smith AM, Chang CH, Lam WY, Redmann V, Freitas TC, Blagih J, van der Windt GJ, Artyomov MN, Jones RG, Pearce EL, Pearce EJ (2014) TLR-driven early glycolytic reprogramming via the kinases TBK1-IKKvarepsilon supports the anabolic demands of dendritic cell activation. Nat Immunol 15:323-332

73. Bonilla FA, Bernstein IL, Khan DA, Ballas ZK, Chinen J, Frank MM, Kobrynski LJ, Levinson AI, Mazer B, Nelson RP Jr, Orange JS, Routes JM, Shearer WT, Sorensen RU, American Academy of Allergy, A., Immunology, American College of Allergy, A., Immunology, Joint Council of Allergy, A. and Immunology (2005) Practice parameter for the diagnosis and management of primary immunodeficiency. Ann Allergy Asthma Immunol 94:S1-S63 
74. Mellander L, Bjorkander J, Carlsson B, Hanson LA (1986) Secretory antibodies in IgA-deficient and immunosuppressed individuals. J Clin Immunol 6:284-291

75. Yazdani R, Azizi G, Abolhassani H, Aghamohammadi A (2017) Selective IgA deficiency: epidemiology, pathogenesis, clinical phenotype, diagnosis, prognosis and management. Scand $\mathbf{J}$ Immunol 85:3-12

76. Benckert J, Schmolka N, Kreschel C, Zoller MJ, Sturm A, Wiedenmann B, Wardemann H (2011) The majority of intestinal $\operatorname{IgA}+$ and $\mathrm{IgG}+$ plasmablasts in the human gut are antigenspecific. J Clin Invest 121:1946-1955

77. Stoop JW, Zegers BJ, Sander PC, Ballieux RE (1969) Serum immunoglobulin levels in healthy children and adults. Clin Exp Immunol 4:101-112

78. Nimmerjahn F, Ravetch JV (2008) Fcgamma receptors as regulators of immune responses. Nat Rev Immunol 8:34-47

79. Guilliams M, Bruhns P, Saeys Y, Hammad H, Lambrecht BN (2014) The function of Fcgamma receptors in dendritic cells and macrophages. Nat Rev Immunol 14:94-108

80. den Dunnen J, Vogelpoel LT, Wypych T, Muller FJ, de Boer L, Kuijpers TW, Zaat SA, Kapsenberg ML, de Jong EC (2012) IgG opsonization of bacteria promotes Th17 responses via synergy between TLRs and FcgammaRIIa in human dendritic cells. Blood 120:112-121

81. Bakema JE, Tuk CW, van Vliet SJ, Bruijns SC, Vos JB, Letsiou S, Dijkstra CD, van Kooyk Y, Brenkman AB, van Egmond $M$ (2015) Antibody-opsonized bacteria evoke an inflammatory dendritic cell phenotype and polyfunctional Th cells by cross-talk between TLRs and FcRs. J Immunol 194:1856-1866

82. Vidarsson G, Dekkers G, Rispens T (2014) IgG subclasses and allotypes: from structure to effector functions. Front Immunol 5:520

83. Beard LJ, Ferrante A, Oxelius VA, Maxwell GM (1986) IgG subclass deficiency in children with $\operatorname{Ig}$ A deficiency presenting with recurrent or severe respiratory infections. Pediatr Res 20:937-942

84. Ugazio AG, Out TA, Plebani A, Duse M, Monafo V, Nespoli L, Burgio GR (1983) Recurrent infections in children with "selective" IgA deficiency: association with $\mathrm{IgG} 2$ and $\mathrm{IgG} 4$ deficiency. Birth Defects Orig Artic Ser 19:169-171

85. Laurent L, Clavel C, Lemaire O, Anquetil F, Cornillet M, Zabraniecki L, Nogueira L, Fournie B, Serre G, Sebbag M (2011) Fcgamma receptor profile of monocytes and macrophages from rheumatoid arthritis patients and their response to immune complexes formed with autoantibodies to citrullinated proteins. Ann Rheum Dis 70:1052-1059

86. Vogelpoel LT, Hansen IS, Visser MW, Nagelkerke SQ, Kuijpers TW, Kapsenberg ML, de Jong EC, den Dunnen J (2015) FcgammaRIIa cross-talk with TLRs, IL-1R, and IFNgammaR selectively modulates cytokine production in human myeloid cells. Immunobiology 220:193-199

87. Clavel C, Nogueira L, Laurent L, Iobagiu C, Vincent C, Sebbag M, Serre G (2008) Induction of macrophage secretion of tumor necrosis factor alpha through Fcgamma receptor IIa engagement by rheumatoid arthritis-specific autoantibodies to citrullinated proteins complexed with fibrinogen. Arthritis Rheum 58:678-688

88. Sokolove J, Zhao X, Chandra PE, Robinson WH (2011) Immune complexes containing citrullinated fibrinogen costimulate macrophages via Toll-like receptor 4 and Fcgamma receptor. Arthritis Rheum 63:53-62

89. Vogelpoel LT, Hansen IS, Rispens T, Muller FJ, van Capel TM, Turina MC, Vos JB, Baeten DL, Kapsenberg ML, de Jong EC, den Dunnen J (2014) Fc gamma receptor-TLR cross-talk elicits pro-inflammatory cytokine production by human M2 macrophages. Nat Commun 5:5444
90. Park JH, Peyrin-Biroulet L, Eisenhut M, Shin JI (2017) IBD immunopathogenesis: a comprehensive review of inflammatory molecules. Autoimmun Rev 16:416-426

91. Ebert EC, Wright SH, Lipshutz WH, Hauptman SP (1984) T-cell abnormalities in inflammatory bowel disease are mediated by interleukin 2. Clin Immunol Immunopathol 33:232-244

92. Mitsuyama K, Sata M, Tanikawa K (1991) Significance of interleukin-6 in patients with inflammatory bowel disease. Gastroenterol Jpn 26:20-28

93. Levin AD, Wildenberg ME, van den Brink GR (2016) Mechanism of action of anti-TNF therapy in inflammatory bowel disease. J Crohns Colitis 10:989-997

94. Cohen BL, Sachar DB (2017) Update on anti-tumor necrosis factor agents and other new drugs for inflammatory bowel disease. BMJ 357:j2505

95. Ungar B, Kopylov U (2016) Advances in the development of new biologics in inflammatory bowel disease. Ann Gastroenterol 29:243-248

96. Sulkanen S, Halttunen T, Laurila K, Kolho KL, Korponay-Szabo IR, Sarnesto A, Savilahti E, Collin P, Maki M (1998) Tissue transglutaminase autoantibody enzyme-linked immunosorbent assay in detecting celiac disease. Gastroenterology 115:1322-1328

97. Sollid LM, Jabri B (2013) Triggers and drivers of autoimmunity: lessons from coeliac disease. Nat Rev Immunol 13:294-302

98. Dieterich W, Ehnis T, Bauer M, Donner P, Volta U, Riecken EO, Schuppan D (1997) Identification of tissue transglutaminase as the autoantigen of celiac disease. Nat Med 3:797-801

99. Marzari R, Sblattero D, Florian F, Tongiorgi E, Not T, Tommasini A, Ventura A, Bradbury A (2001) Molecular dissection of the tissue transglutaminase autoantibody response in celiac disease. J Immunol 166:4170-4176

100. Di Niro R, Mesin L, Zheng NY, Stamnaes J, Morrissey M, Lee JH, Huang M, Iversen R, du Pre MF, Qiao SW, Lundin KE, Wilson PC, Sollid LM (2012) High abundance of plasma cells secreting transglutaminase 2 -specific IgA autoantibodies with limited somatic hypermutation in celiac disease intestinal lesions. Nat Med 18:441-445

101. Brennan FM, McInnes IB (2008) Evidence that cytokines play a role in rheumatoid arthritis. J Clin Invest 118:3537-3545

102. Koenders MI, van den Berg WB (2015) Novel therapeutic targets in rheumatoid arthritis. Trends Pharmacol Sci 36:189-195

103. Aho K, Heliovaara M, Maatela J, Tuomi T, Palosuo T (1991) Rheumatoid factors antedating clinical rheumatoid arthritis. J Rheumatol 18:1282-1284

104. van Leeuwen MA, Westra J, van Riel PL, Limburg PC, van Rijswijk MH (1995) IgM, IgA, and IgG rheumatoid factors in early rheumatoid arthritis predictive of radiological progression? Scand J Rheumatol 24:146-153

105. Quirke AM, Fisher BA, Kinloch AJ, Venables PJ (2011) Citrullination of autoantigens: upstream of TNFalpha in the pathogenesis of rheumatoid arthritis. FEBS Lett 585:3681-3688

106. Kokkonen H, Mullazehi M, Berglin E, Hallmans G, Wadell G, Ronnelid J, Rantapaa-Dahlqvist S (2011) Antibodies of IgG, IgA and IgM isotypes against cyclic citrullinated peptide precede the development of rheumatoid arthritis. Arthritis Res Ther 13:R13

107. Rantapaa-Dahlqvist S, de Jong BA, Berglin E, Hallmans G, Wadell G, Stenlund H, Sundin U, van Venrooij WJ (2003) Antibodies against cyclic citrullinated peptide and $\operatorname{IgA}$ rheumatoid factor predict the development of rheumatoid arthritis. Arthritis Rheum 48:2741-2749

108. Anquetil F, Clavel C, Offer G, Serre G, Sebbag M (2015) IgM and $\operatorname{IgA}$ rheumatoid factors purified from rheumatoid arthritis sera boost the Fc receptor- and complement-dependent effector functions of the disease-specific anti-citrullinated protein autoantibodies. J Immunol 194:3664-3674 
109. Goh FG, Midwood KS (2012) Intrinsic danger: activation of Tolllike receptors in rheumatoid arthritis. Rheumatology (Oxford) 51:7-23

110. Tan Sardjono C, Mottram PL, van de Velde NC, Powell MS, Power D, Slocombe RF, Wicks IP, Campbell IK, McKenzie SE, Brooks M, Stevenson AW, Hogarth PM (2005) Development of spontaneous multisystem autoimmune disease and hypersensitivity to antibody-induced inflammation in Fcgamma receptor IIa-transgenic mice. Arthritis Rheum 52:3220-3229

111. Van de Velde NC, Mottram PL, Powell MS, Lim B, Holmdahl R, Hogarth PM (2010) Transgenic mice expressing human FcgammaRIIa have enhanced sensitivity to induced autoimmune arthritis as well as elevated Th17 cells. Immunol Lett 130:82-88

112. el Bannoudi H, Ioan-Facsinay A, Toes RE (2014) Bridging autoantibodies and arthritis: the role of Fc receptors. Curr Top Microbiol Immunol 382:303-319

113. Vogelpoel LT, Baeten DL, de Jong EC, den Dunnen J (2015) Control of cytokine production by human fc gamma receptors: implications for pathogen defense and autoimmunity. Front Immunol 6:79

114. Zhang C, Zeng X, Li Z, Wang Z, Li S (2015) Immunoglobulin A nephropathy: current progress and future directions. Transl Res 166:134-144

115. Berthelot L, Papista C, Maciel TT, Biarnes-Pelicot M, Tissandie E, Wang PH, Tamouza H, Jamin A, Bex-Coudrat J, Gestin A, Boumediene A, Arcos-Fajardo M, England P, Pillebout E, Walker F, Daugas E, Vrtosvnik F, Flamant M, Benhamou M, Cogne M, Moura IC, Monteiro RC (2012) Transglutaminase is essential for IgA nephropathy development acting through IgA receptors. J Exp Med 209:793-806

116. Aleyd E, Heineke MH, van Egmond M (2015) The era of the immunoglobulin A Fc receptor FcalphaRI; its function and potential as target in disease. Immunol Rev 268:123-138

117. Mihai S, Sitaru C (2007) Immunopathology and molecular diagnosis of autoimmune bullous diseases. J Cell Mol Med 11:462-481

118. van der Steen LP, Bakema JE, Sesarman A, Florea F, Tuk CW, Kirtschig G, Hage JJ, Sitaru C, van Egmond M (2012) Blocking Fcalpha receptor I on granulocytes prevents tissue damage induced by IgA autoantibodies. J Immunol 189:1594-1601

119. Collin P, Salmi TT, Hervonen K, Kaukinen K, Reunala T (2017) Dermatitis herpetiformis: a cutaneous manifestation of coeliac disease. Ann Med 49:23-31

120. Nagelkerke SQ, Kuijpers TW (2014) Immunomodulation by IVIg and the role of Fc-gamma receptors: classic mechanisms of action after all? Front Immunol 5:674

121. Rossato E, Ben Mkaddem S, Kanamaru Y, Hurtado-Nedelec M, Hayem G, Descatoire V, Vonarburg C, Miescher S, Zuercher AW, Monteiro RC (2015) Reversal of arthritis by human monomeric IgA through the receptor-mediated SH2 domain-containing phosphatase 1 inhibitory pathway. Arthritis Rheumatol 67:1766-1777

122. Meyer S, Nederend M, Jansen JH, Reiding KR, Jacobino SR, Meeldijk J, Bovenschen N, Wuhrer M, Valerius T, Ubink R, Boross P, Rouwendal G, Leusen JH (2016) Improved in vivo anti-tumor effects of IgA-Her2 antibodies through half-life extension and serum exposure enhancement by FcRn targeting. MAbs 8:87-98

123. Lohse S, Meyer S, Meulenbroek LA, Jansen JH, Nederend M, Kretschmer A, Klausz K, Moginger U, Derer S, Rosner T, Kellner C, Schewe D, Sondermann P, Tiwari S, Kolarich D, Peipp M, Leusen JH, Valerius T (2016) An anti-EGFR IgA that displays improved pharmacokinetics and myeloid effector cell engagement in vivo. Cancer Res 76:403-417

124. Weinblatt ME, Kavanaugh A, Genovese MC, Musser TK, Grossbard EB, Magilavy DB (2010) An oral spleen tyrosine kinase (Syk) inhibitor for rheumatoid arthritis. N Engl J Med 363:1303-1312

125. Hang L, Blum AM, Kumar S, Urban JF Jr, Mitreva M, Geary TG, Jardim A, Stevenson MM, Lowell CA, Weinstock JV (2016) Downregulation of the Syk signaling pathway in intestinal dendritic cells is sufficient to induce dendritic cells that inhibit colitis. J Immunol 197:2948-2957

126. Stark AK, Sriskantharajah S, Hessel EM, Okkenhaug K (2015) PI3K inhibitors in inflammation, autoimmunity and cancer. Curr Opin Pharmacol 23:82-91

127. Gadina M, Gazaniga N, Vian L, Furumoto Y (2017) Small molecules to the rescue: inhibition of cytokine signaling in immunemediated diseases. J Autoimmun 85:20-31

128. Ogasawara N, Sasaki M, Itoh Y, Tokudome K, Kondo Y, Ito Y, Tanida S, Kamiya T, Kataoka H, Joh T, Kasugai K (2011) Rebamipide suppresses TLR-TBK1 signaling pathway resulting in regulating IRF3/7 and IFN-alpha/beta reduction. J Clin Biochem Nutr 48:154-160

129. Reilly SM, Chiang SH, Decker SJ, Chang L, Uhm M, Larsen MJ, Rubin JR, Mowers J, White NM, Hochberg I, Downes M, Yu RT, Liddle C, Evans RM, Oh D, Li P, Olefsky JM, Saltiel AR (2013) An inhibitor of the protein kinases TBK1 and IKK-varepsilon improves obesity-related metabolic dysfunctions in mice. Nat Med 19:313-321

130. Sadowski MC, Pouwer RH, Gunter JH, Lubik AA, Quinn RJ, Nelson CC (2014) The fatty acid synthase inhibitor triclosan: repurposing an anti-microbial agent for targeting prostate cancer. Oncotarget 5:9362-9381

131. Jones SF, Infante JR (2015) Molecular pathways: fatty acid synthase. Clin Cancer Res 21:5434-5438

132. Leusen JH (2015) IgA as therapeutic antibody. Mol Immunol 68:35-39

133. Sica A, Schioppa T, Mantovani A, Allavena P (2006) Tumourassociated macrophages are a distinct M2 polarised population promoting tumour progression: potential targets of anti-cancer therapy. Eur J Cancer 42:717-727

134. Heusinkveld M, van der Burg SH (2011) Identification and manipulation of tumor associated macrophages in human cancers. J Transl Med 9:216

135. Marvel D, Gabrilovich DI (2015) Myeloid-derived suppressor cells in the tumor microenvironment: expect the unexpected. $\mathrm{J}$ Clin Invest 125:3356-3364

136. Stockmeyer B, Dechant M, van Egmond M, Tutt AL, Sundarapandiyan K, Graziano RF, Repp R, Kalden JR, Gramatzki M, Glennie MJ, van de Winkel JG, Valerius T (2000) Triggering Fc alpha-receptor I (CD89) recruits neutrophils as effector cells for CD20-directed antibody therapy. J Immunol 165:5954-5961

137. Otten MA, Rudolph E, Dechant M, Tuk CW, Reijmers RM, Beelen RH, van de Winkel JG, van Egmond M (2005) Immature neutrophils mediate tumor cell killing via IgA but not $\operatorname{IgG} \mathrm{Fc}$ receptors. J Immunol 174:5472-5480

138. Dechant M, Beyer T, Schneider-Merck T, Weisner W, Peipp M, van de Winkel JG, Valerius T (2007) Effector mechanisms of recombinant $\operatorname{IgA}$ antibodies against epidermal growth factor receptor. J Immunol 179:2936-2943

139. Sakamoto N, Shibuya K, Shimizu Y, Yotsumoto K, Miyabayashi T, Sakano S, Tsuji T, Nakayama E, Nakauchi H, Shibuya A (2001) A novel Fc receptor for IgA and IgM is expressed on both hematopoietic and non-hematopoietic tissues. Eur J Immunol 31:1310-1316

140. Shibuya A, Sakamoto N, Shimizu Y, Shibuya K, Osawa M, Hiroyama T, Eyre HJ, Sutherland GR, Endo Y, Fujita T, Miyabayashi T, Sakano S, Tsuji T, Nakayama E, Phillips JH, Lanier LL, Nakauchi H (2000) Fc alpha/mu receptor mediates endocytosis of IgM-coated microbes. Nat Immunol 1:441-446 
141. Moura IC, Centelles MN, Arcos-Fajardo M, Malheiros DM, Collawn JF, Cooper MD, Monteiro RC (2001) Identification of the transferrin receptor as a novel immunoglobulin (Ig)A1 receptor and its enhanced expression on mesangial cells in $\operatorname{IgA}$ nephropathy. J Exp Med 194:417-425

142. Moura IC, Arcos-Fajardo M, Gdoura A, Leroy V, Sadaka C, Mahlaoui N, Lepelletier Y, Vrtovsnik F, Haddad E, Benhamou M, Monteiro RC (2005) Engagement of transferrin receptor by polymeric IgA1: evidence for a positive feedback loop involving increased receptor expression and mesangial cell proliferation in IgA nephropathy. J Am Soc Nephrol 16:2667-2676

143. Tamouza H, Vende F, Tiwari M, Arcos-Fajardo M, Vrtovsnik F, Benhamou M, Monteiro RC, Moura IC (2007) Transferrin receptor engagement by polymeric $\mathrm{IgA} 1$ induces receptor expression and mesangial cell proliferation: role in IgA nephropathy. Contrib Nephrol 157:144-147

144. Stockert RJ, Kressner MS, Collins JC, Sternlieb I, Morell AG (1982) IgA interaction with the asialoglycoprotein receptor. Proc Natl Acad Sci USA 79:6229-6231

145. Tomana M, Kulhavy R, Mestecky J (1988) Receptor-mediated binding and uptake of immunoglobulin A by human liver. Gastroenterology 94:762-770
146. Rifai A, Fadden K, Morrison SL, Chintalacharuvu KR (2000) The $\mathrm{N}$-glycans determine the differential blood clearance and hepatic uptake of human immunoglobulin (Ig)A1 and IgA2 isotypes. J Exp Med 191:2171-2182

147. Wilson TJ, Fuchs A, Colonna M (2012) Cutting edge: human FcRL4 and FcRL5 are receptors for IgA and IgG. J Immunol 188:4741-4745

148. Diana J, Moura IC, Vaugier C, Gestin A, Tissandie E, Beaudoin L, Corthesy B, Hocini H, Lehuen A, Monteiro RC (2013) Secretory $\operatorname{Ig} \mathrm{A}$ induces tolerogenic dendritic cells through SIGNR1 dampening autoimmunity in mice. J Immunol 191:2335-2343

149. Lamkhioued B, Gounni AS, Gruart V, Pierce A, Capron A, Capron M (1995) Human eosinophils express a receptor for secretory component. Role in secretory IgA-dependent activation. Eur J Immunol 25:117-125

150. Mantis NJ, Cheung MC, Chintalacharuvu KR, Rey J, Corthesy B, Neutra MR (2002) Selective adherence of IgA to murine Peyer's patch M cells: evidence for a novel IgA receptor. J Immunol 169:1844-1851 